NASA Technical Memorandum 106254

AIAA-93-2538

\title{
Lubrication of an 85-mm Ball Bearing with RP-1
}

Harold E. Addy, Jr.

National Aeronautics and Space Administration

Lewis Research Center

Cleveland, Ohio

and

Frederick T. Schuller

Sverdrup Technology, Inc.

Lewis Research Center Group

Brook Park, Ohio

Prepared for the

29th AIAA Joint Propulsion Conference and Exhibit

sponsored by the AIAA, SAE, ASME, and ASEE

Monterey, California, June 28-30, 1993

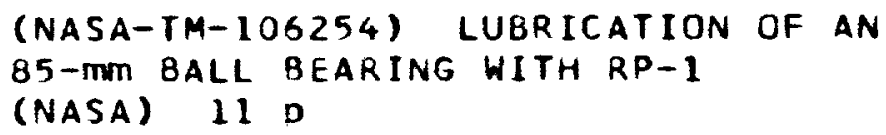

N93-31670

Unclas 



\title{
LUBRICATION OF AN 85-MM BALL BEARING WITH RP-1
}

\author{
Harold E. Addy, Jr.* \\ NASA Lewis Research Center \\ Cleveland, Ohio \\ and \\ Fredrick T. Schuller \\ Sverdrup Technology, Inc. \\ Cleveland, Ohio
}

\begin{abstract}
A parametric experimental investigation of an 85 millimeter bore angular contact ball bearing running in RP-1 fuel was performed at speeds of 10 000 to 24000 RPM. Thrust loads were varied from 4450 to 17800 Newtons (1000 to 4000 lbs.). Radial loads were varied from 1335 to 13350 Newtons (300 to 3000 lbs.). RP-1 lubrication for the bearing was provided through a stationary jet ring located adjacent to the test bearing outer ring.

Increases in both the thrust and radial loads resulted in increased bearing temperature, while increases in shaft speed resulted in much more dramatic increases in bearing temperature. These trends are typical for ball bearings operating under these types of conditions. Results are given for outer ring temperatures of the test bearing at the various test conditions employed. In addition, the heat energy removed from the bearing by the RP-1 was determined by measuring the increase in temperature as the RP-1 passed through the bearing. Results showed that the amount of heat energy removed by the RP-1 increased with both shaft speed and RP-1 flow rate to the bearing.
\end{abstract}

\section{INTRODUCTION}

The hydrocarbon fuel RP-1 has been and continues to be used by a number of rocket

\footnotetext{
* Aerospace Engineer, Launch Vehicle Propulsion Branch, Member AIAA
}

Copyright (C) 1993 by the American Institute of Aeronautics and Astronautics, Inc., 1993. All rights reserved. No copyright is asserted in the United States under Title 17, U.S. Code. The U.S. Government has a royalty-free license to exercise all rights under the copyright claimed herein for Governmental purposes. All other rights are reserved by the copyright owner. propulsion systems. Among them are the F-1 engine used in the Apollo program which is no longer in production as well as the RS-27A engine used in the Delta II program and the MA-5A engine used in the Atlas II program, both of which are in current production. As various concepts are considered for future launch systems, RP-1 continues to be a viable fuel option. Because more emphasis is being placed on reliability, durability, maintainability, and cost effectiveness in the new design concepts, more information about the effects the various fuels have on the rocket engine systems is needed. Liquid fueled rocket engines typically utilize turbopumps to transfer the fuel and oxidizer from the storage tanks to the combustion chamber. To reduce the weight and complexity of these turbopumps, their bearings are often lubricated and cooled by the liquid being pumped rather than having a separate lubrication system. A few limited investigations of the lubricating capabilities of RP-1 have been performed. $1,2,3$ However, in order to more thoroughly assess the impact of RP-1 on rocket engine turbopump bearing performance and reliability, a test program operating ball bearings in an RP-1 environment has been undertaken at the NASA Lewis Research Center. A specific goal of this program is to establish a database of bearing performance in RP-1 over a range of DN numbers from 0.85 to 2.1 million and a range of Hertzian contact stress levels from 1518 to $2802 \mathrm{~N} / \mathrm{mm}^{2}$ $(220,200$ to $406,400 \mathrm{psi})$. Such an extensive database, which covers the operating range for most turbopump designs, has not been established until now. Moreover, the program establishes the outer ring temperature limit for the test bearings running in RP-1. The investigation also points out the significance of RP-1 flow to the bearing since overlubrication of the bearings markedly increases the shaft power lost to the bearings. The documentation of this information will permit much more precision in bearing designs for future rocket engine turbopump applications. 
Angular contact ball bearings continue to be a leading choice for these applications for a number of reasons, among which are: 1)large capacity-tovolume ratio, 2)the ability to operate independent of external pressurizing systems, 3)the ability to operate without sudden seizure after ingesting foreign material, 4)low heat generation and lubricant consumption, and 5)tolerance for brief periods of lubricant starvation. A bearing having a bore of $\mathbf{8 5}$ $\mathrm{mm}$ was selected for testing under both thrust and radial loads in a test rig that was modified for this program. ${ }^{4}$ The test bearing was a separable angular contact bearing with thirteen-22.2 $\mathrm{mm}(0.875$ in) diameter balls. The inner and outer rings, as well as the balls, were made of M50 tool steel as per AMS 6491 and had a hardness of Rc 61-64. The cages were made of silver plated SAE 4340 steel and were outer ring guided.

Parametric tests were performed to establish the lubricating capabilities of RP-1 pertaining to ball bearings. Shaft speed was varied from 10000 to 24 000 RPM. Thrust loads were varied from 4450 to 17 800 Newtons ( 1000 to 4000 lbs.) and radial loads were varied from 1335 to $13350 \mathrm{~N}$ (300 to 3000 lbs.), while RP-1 flow rate was varied from 0.76 to 3.03 liters $/ \mathrm{min}(\mathrm{lpm})$ (0.2 to $0.8 \mathrm{gpm})$.

\section{TEST RIG DESCRIPTION}

A cross-sectional drawing of the bearing test rig used in this program is shown in Fig. 1. The test bearing was installed near the center of the vertically mounted shaft. An angular contact ball bearing identical to the baseline test bearing was used as the upper support bearing, while a smaller, roller bearing was used as the bottom support bearing. The outer ring of the test bearing was mounted in an annular shaped, floating housing which was suspended from above by a series of rods and restrained laterally by a steel belt. This arrangement allowed the application of both thrust and radial loads to the test bearing. The thrust load was applied by nitrogen gas pressurization of a metal bellows located at the top of the rig, while the radial load was similarly applied by a bellows located at the side of the rig. The test bearing was lubricated by injecting RP-1 onto the balls and inner raceway of the test bearing as shown in Fig. 2. The RP-1 was injected through a series of holes in an annular jet ring located adjacent to, and just above the test bearing.

Temperatures of the outer ring of the test bearing were measured through three spring loaded

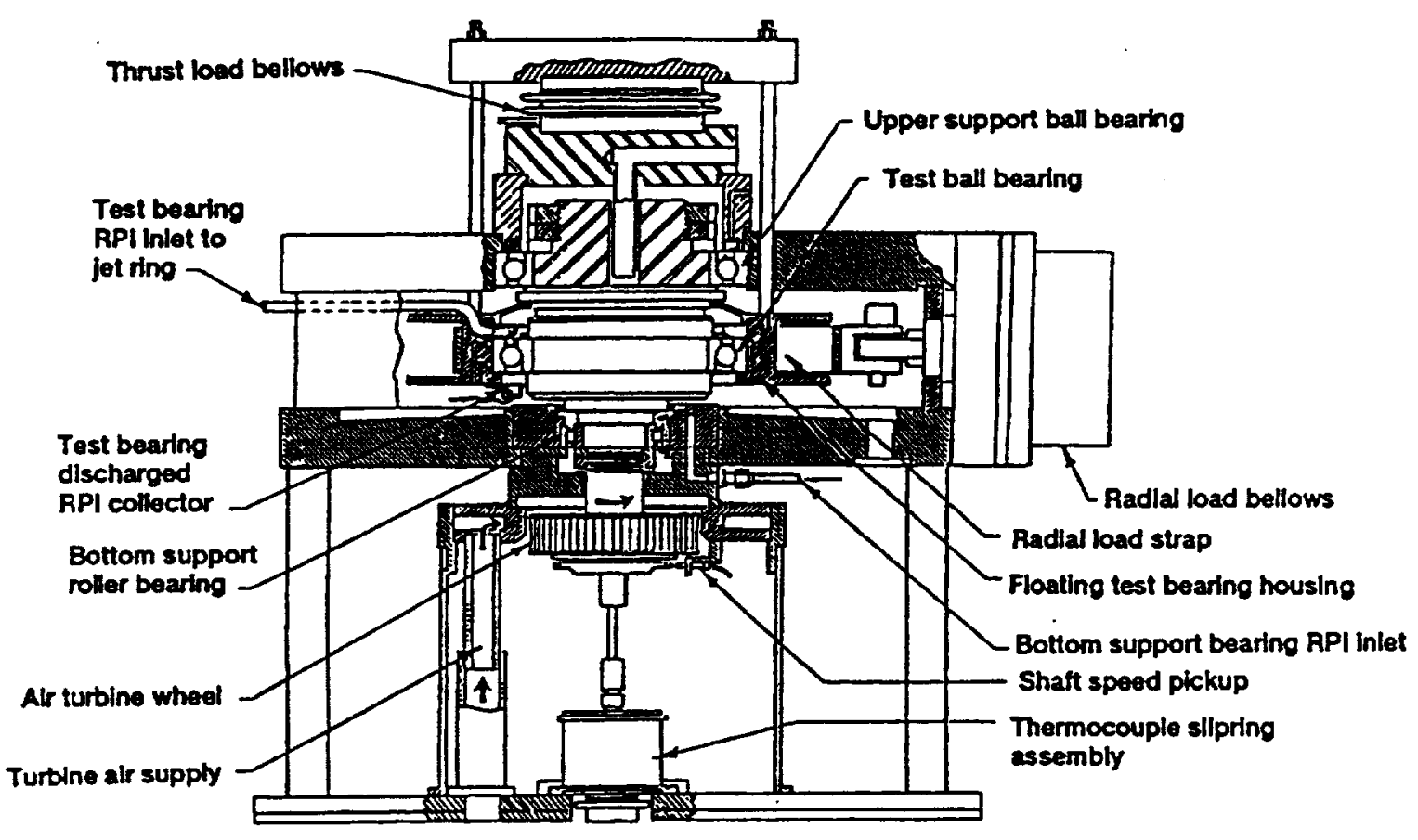

Figure 1. RP-1 Bearing Rig 


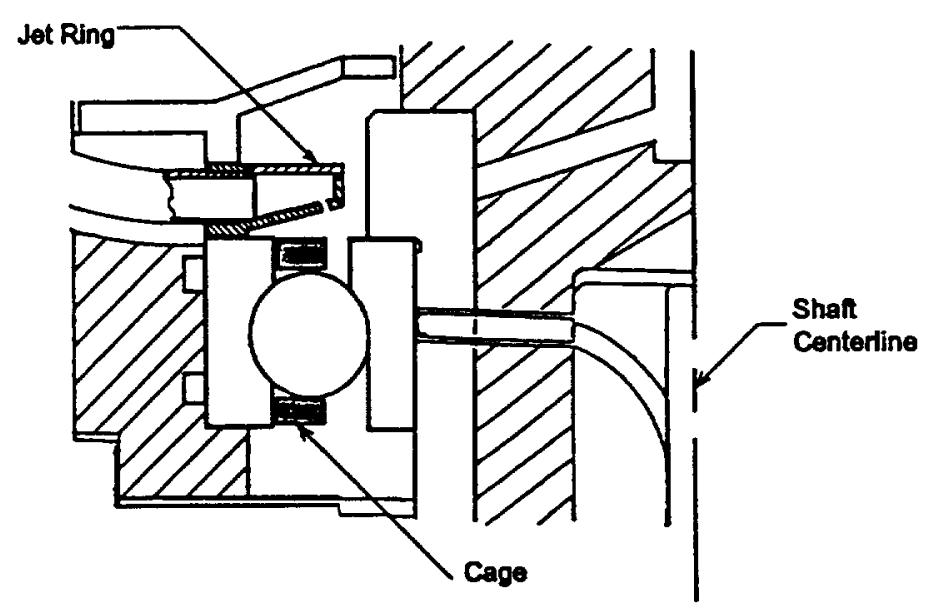

Figure 2. Jet Ring for Test Bearing Lubrication

thermocouples. The three thermocouples were mounted in the annular test bearing housing and were equally spaced around the circumference of the outer ring with one located $15^{\circ}$ from the radial load bearing zone.

Both RP-1 inlet and outlet lubricant temperatures to the test bearing were continuously monitored. The inlet RP-1 temperature was measured upstream of the test bearing jet ring while the outlet RP-1 temperature was measured by allowing the discharged RP-1 to drain through a hole in the bottom of a small cup which had a thermocouple mounted inside. The cup was located just below the test bearing. The flow rate of RP-1 through the jet ring to the test bearing was measured by an in-line turbine flow meter.

The shaft was driven by an air turbine located near the bottom of the shaft. Shaft speed was monitored by a magnetic probe which sensed the motion of a sixty tooth gear attached to the bottom of the shaft.

\section{TEST BEARING}

The test bearing was an ABEC-7 grade, 85 millimeter bore, separable angular contact ball bearing with a double outer land riding cage. It contained 13 balls; each $22.2 \mathrm{~mm}$ ( 0.875 inches) in diameter. Complete specifications are shown in Table I.

\section{LUBRICANT}

The lubricant used in this program was RP1 , a mixture of hydrocarbons qualified to the MIL-S$25576 \mathrm{C}$ specifications. Its properties allow it to fall

TABLE I. - TEST BEARING SPECIFICATIONS

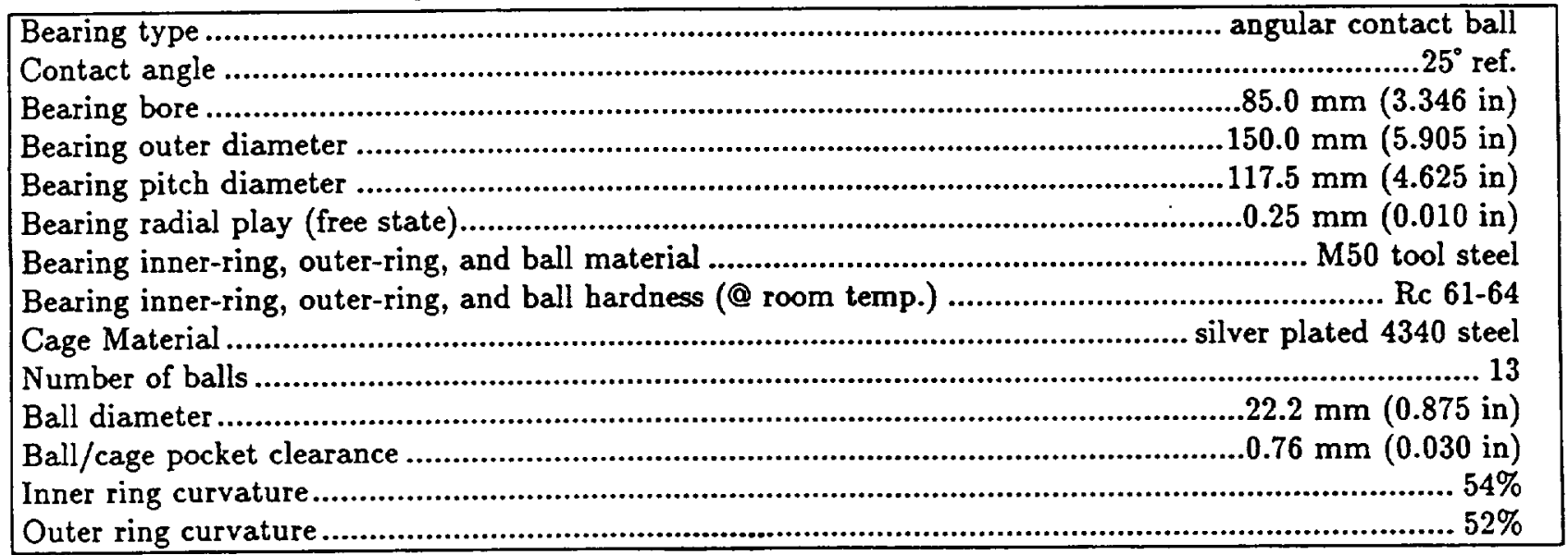


into a range of fuels commonly referred to as "kerosene". 5 The major properties ${ }^{6}$ of RP-1 are given in Table II. The heat capacity of liquid RP-1 between -45 and $310^{\circ} \mathrm{C}(-50$ and $500 \mathrm{~F})$ can be approximated by: ${ }^{7}$

$$
c_{p}=1.88+0.0041 \mathrm{~T}
$$

where: $\quad c_{p}=$ specific heat, $\mathrm{kJ} / \mathrm{kg} \cdot{ }^{\circ} \mathrm{C}$

$$
\mathrm{T}=\text { temperature, }{ }^{\circ} \mathrm{C}
$$

TABLE II. - PROPERTIES OF RP-1

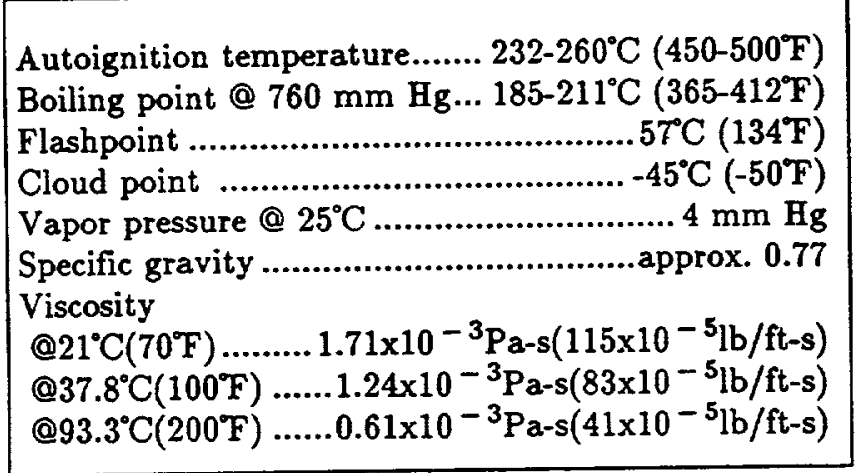

\section{TEST PROCEDURE}

Before test shaft rotation, a small (1335 N or $300 \mathrm{lb}$.) thrust load was applied to both the test and upper support bearings to ensure that the bearing balls were properly engaged in the ring raceways. As the shaft speed was increased, a small $(1335 \mathrm{~N}$ or $300 \mathrm{lb}$.) radial load was applied to ensure that the lower support roller bearing was not running unloaded. The thrust load was then increased to the desired value as the shaft was brought to speed. Test parameters are shown in Table III. The maximum Hertzian contact stresses to which the test bearings were subjected at the various load and speed combinations as calculated by the rolling element bearing computer code SHABERTH ${ }^{8}$ are shown in Table IV. In conventional ball bearing design practice, maximum Hertzian contact stresses are limited to $2070 \mathrm{~N} / \mathrm{mm}^{2}(300,000 \mathrm{psi})$.

The flow rate of the RP-1 to the test bearing was set to approximately $3.8 \mathrm{lpm}(1.0 \mathrm{gpm})$ during startup, then, after the speed and loads were established, the RP-1 flow rate was set to $3.03 \mathrm{lpm}$ $(0.8 \mathrm{gpm})$. After the bearing temperatures stabilized at the set conditions ( 15 to 20 minutes), the flow rate was lowered to $1.89 \mathrm{lpm}(0.5 \mathrm{gpm})$ and again the bearing temperatures were allowed to stabilize. This procedure was repeated for $1.14 \mathrm{lpm}(0.3 \mathrm{gpm})$ and again for $0.76 \mathrm{lpm}(0.2 \mathrm{gpm})$. Early results of this program, which are discussed in Reference 9, indicated that the higher operating conditions, at speeds above $15000 \mathrm{rpm}$ and RP-1 flow rates below $0.76 \mathrm{lpm}(0.2 \mathrm{gpm})$ led to bearing temperatures that would not reach a steady state value. Rather, the temperature continued to rise toward an unsafe value indicating that the bearing had lost sufficient coolant flow. Furthermore, the shaft speed decreased considerably, indicating that the bearing torque had increased and suggesting that the RP-1 lubricating film in the bearing had broken down. These conditions cause the bearing to overheat quickly. For these reasons, results presented here are limited to a minimum flow rate of $0.76 \mathrm{lpm}(0.2 \mathrm{gpm})$.

The RP-1 was pumped from a 115 liter (30 gallon) holding tank, through the bearings in the test rig and back to the holding tank. After a warmup period of approximately 15 minutes, the RP-1 in the holding tank would rise to a temperature of $38^{\circ} \mathrm{C}\left(100^{\circ} \mathrm{F}\right)$ or greater. In order to obtain a constant RP-1 supply temperature of $27^{\circ} \mathrm{C}$ $\left(80^{\circ} \mathrm{F}\right)$ to the test bearing for all conditions tested, a heat exchanger was installed in the system between the holding tank and the rig to cool the RP-1 from the holding tank. The $27^{\circ} \mathrm{C}\left(80^{\circ} \mathrm{F}\right)$ inlet temperature of the RP-1 to the test bearing was selected partly due to the limitations of the cooling water available

\begin{tabular}{|c|c|c|c|c|}
\hline \multirow{2}{*}{$\begin{array}{l}\text { SPEEDS } \\
\text { RPM } \\
\end{array}$} & \multicolumn{2}{|c|}{ LOADS } & \multirow{2}{*}{$\begin{array}{c}\text { RP-1 FLOW RATES } \\
\text { TO TEST BEARING } \\
\text { lpm (gpm) }\end{array}$} & \multirow{2}{*}{$\begin{array}{l}\text { RP-1 INLET } \\
\text { TEMP. } \\
{ }^{\circ} \mathrm{C}\left({ }^{\circ} \mathrm{F}\right)\end{array}$} \\
\hline & $\begin{array}{c}\text { THRUST } \\
\text { N (lbs.) }\end{array}$ & $\begin{array}{r}\text { RADIAL } \\
\text { N (lbs.) }\end{array}$ & & \\
\hline 10000 & $4450(1000)$ & $1335(300)$ & $0.76(0.20)$ & $27(80)$ \\
\hline 15000 & $8900(2000)$ & $4450(1000)$ & $1.14(0.30)$ & \\
\hline 20000 & $13340(3000)$ & $8900(2000)$ & $1.89(0.50)$ & \\
\hline 24000 & $17800(4000)$ & $13340(3000)$ & $3.03(0.80)$ & \\
\hline
\end{tabular}

TABLE III. - TEST PARAMETERS 
TABLE IV. - HERTZIAN CONTACT STRESSES

\begin{tabular}{|c|c|c|c|c|}
\hline \multirow{2}{*}{$\begin{array}{c}\text { SPEEDS } \\
\text { RPM } \\
\end{array}$} & \multicolumn{2}{|c|}{ LOADS } & \multicolumn{2}{|c|}{$\begin{array}{c}\text { MAX. HERTZIAN } \\
\text { CONTACT STRESS }\end{array}$} \\
\hline & $\begin{array}{l}\text { THRUST } \\
\text { N (lbs.) }\end{array}$ & $\begin{array}{l}\text { RADIAL } \\
\text { N (lbs.) }\end{array}$ & $\begin{array}{c}\mathrm{CON} \\
\mathrm{N} / \mathrm{mm}^{2}\end{array}$ & $\begin{array}{l}\text { TRESS } \\
\left(\mathrm{psi} * 10^{5}\right) \\
\end{array}$ \\
\hline 10000 & $4450(1000)$ & $1335(300)$ & 1542 & 2.236 \\
\hline$n$ & $8900(2000)$ & $n$ & 1788 & 2.593 \\
\hline & $17800(4000)$ & $n$ & 2164 & 3.139 \\
\hline 15000 & $4450(1000)$ & $1335(300)$ & 1518 & 2.202 \\
\hline ” & $8900(2000)$ & $n$ & 1770 & 2.567 \\
\hline " & $13350(3000)$ & $n$ & 1990 & 2.886 \\
\hline 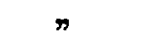 & $17800(4000)$ & 》 & 2167 & 3.143 \\
\hline$n$ & $13350(3000)$ & $4450(1000)$ & 2204 & 3.197 \\
\hline n & $13350(3000)$ & $8900(2000)$ & 2538 & 3.681 \\
\hline 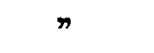 & $13350(3000)$ & $13350(3000)$ & 2802 & 4.064 \\
\hline 20000 & $4450(1000)$ & $1335(300)$ & 1587 & 2.302 \\
\hline$n$ & $8900(2000)$ & $n$ & 1765 & 2.560 \\
\hline$\pi$ & $13350(3000)$ & 7 & 1980 & 2.870 \\
\hline 24000 & $4450(1000)$ & $1335(300)$ & 1718 & 2.492 \\
\hline
\end{tabular}

to the heat exchanger at the test facility, but was determined to be a valid inlet temperature for this program.

\section{RESULTS AND DISCUSSION}

Parametric tests were conducted on an 85 millimeter-bore, angular contact ball bearing. The results of these tests are presented in this section. They are discussed primarily in terms of bearing outer ring temperature versus the various operating parameters. The outer ring temperature of the bearing was determined by averaging the measurements of the three thermocouples equally spaced around the circumference of the outer ring of the test bearing.

\section{Effect of Load and Shaft Speed on Bearing Temperature}

The effect of thrust load on bearing temperature at three different speeds is shown in Fig. 3. In general, as the thrust load is increased, the bearing temperature increases. However, at 10000 $\mathrm{rpm}$, the increase in temperature of the bearing is modest (about $5^{\circ} \mathrm{C}$ ) as the thrust load on the bearing is quadrupled from $4480 \mathrm{~N}$ (1000 lb.) to $17800 \mathrm{~N}$ $(4000 \mathrm{lb}$.). At $15000 \mathrm{rpm}$, the increase in bearing temperature is more significant as the thrust load on the bearing is increased over that same range. When the bearing is operated at a shaft speed of 20000 rpm, the increase in bearing temperature is even more significant. Reliable data could not be obtained for a thrust load of $17800 \mathrm{~N}(4000 \mathrm{lb}$.) at 20000 rpm because it was found that at bearing outer ring

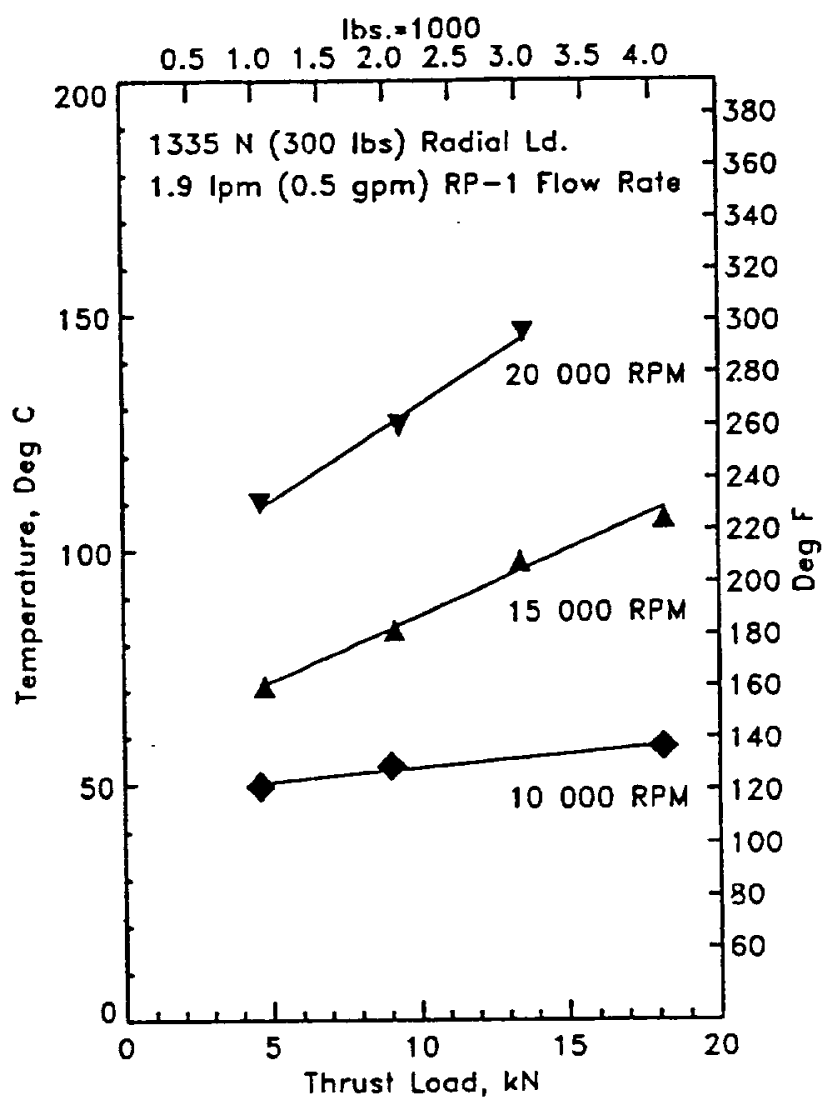

Figure 3. Effect of Thrust Load on Outer Ring Temperature for Various Shaft Speeds 
temperatures of $150^{\circ} \mathrm{C}\left(300^{\circ} \mathrm{F}\right)$ and above the lubricating and cooling capabilities of RP-1 begin to change, as will be discussed later. Overall, it is apparent that as the shaft speed increases, the bearing becomes more sensitive to changes in thrust load conditions as evidenced by the increasing slope of the curves for each increase in speed. A leastsquares curve fit for the bearing temperatures versus thrust load at each speed gives a curve of the form:

$$
\mathrm{T},{ }^{\circ} \mathrm{C}=\mathrm{TL}_{0}+\mathrm{TL}_{1} * \mathrm{P}_{t}
$$

where $P_{t}$ is the thrust load in $k N$ and the coefficients $\mathrm{TL}_{0}$ an $\mathrm{TL}_{1}$ are given in Table $\mathrm{V}$.

TABLE V - TEMP. VS. THRUST LD. COEF.

\begin{tabular}{|c|c|c|}
\hline Speed & $\mathrm{TL}_{0}$ & $\mathrm{TL}_{1}$ \\
\hline 10000 & 47.6 & 0.594 \\
\hline 15000 & 58.0 & 2.82 \\
\hline 20000 & 90.6 & 4.03 \\
\hline
\end{tabular}

Note that each of these curves gives a different temperature when extrapolated to a condition of zero thrust load. This is because the balls are subjected to different centrifugal forces at different shaft speeds even when no thrust load is applied.

Figure 4 depicts how bearing temperature varies with a change in radial load for several different flow rates. Again, modest increases in bearing temperature result from increases in radial load. A least-squares curve fit through the points for each flow rate in Fig. 4 yields a curve of the form:

$$
\mathrm{T},{ }^{\circ} \mathrm{C}=\mathrm{RL}_{0}+\mathrm{RL}_{1} \dot{\mathrm{V}}
$$

where $\dot{V}$ is the RP-1 flow rate in lpm. The coefficients $R L_{0}$ and $R L_{1}$ are given in Table VI.

\begin{tabular}{|c|c|c|c|}
\hline $\begin{array}{l}\text { Flor } \\
\text { lpm }\end{array}$ & $\begin{array}{l}\text { rate } \\
\text { gpm }\end{array}$ & $\mathrm{RL}_{0}$ & $\mathrm{RL}_{1}$ \\
\hline 0.76 & 0.20 & 129. & 0.94 \\
\hline 1.14 & 0.30 & 114. & 1.20 \\
\hline 1.89 & 0.50 & 95. & 1.36 \\
\hline 3.03 & 0.80 & 80. & 1.18 \\
\hline
\end{tabular}

TABLE VI - TEMP. VS. RADIAL LD. COEF.

Note that like the curves for bearing temperature

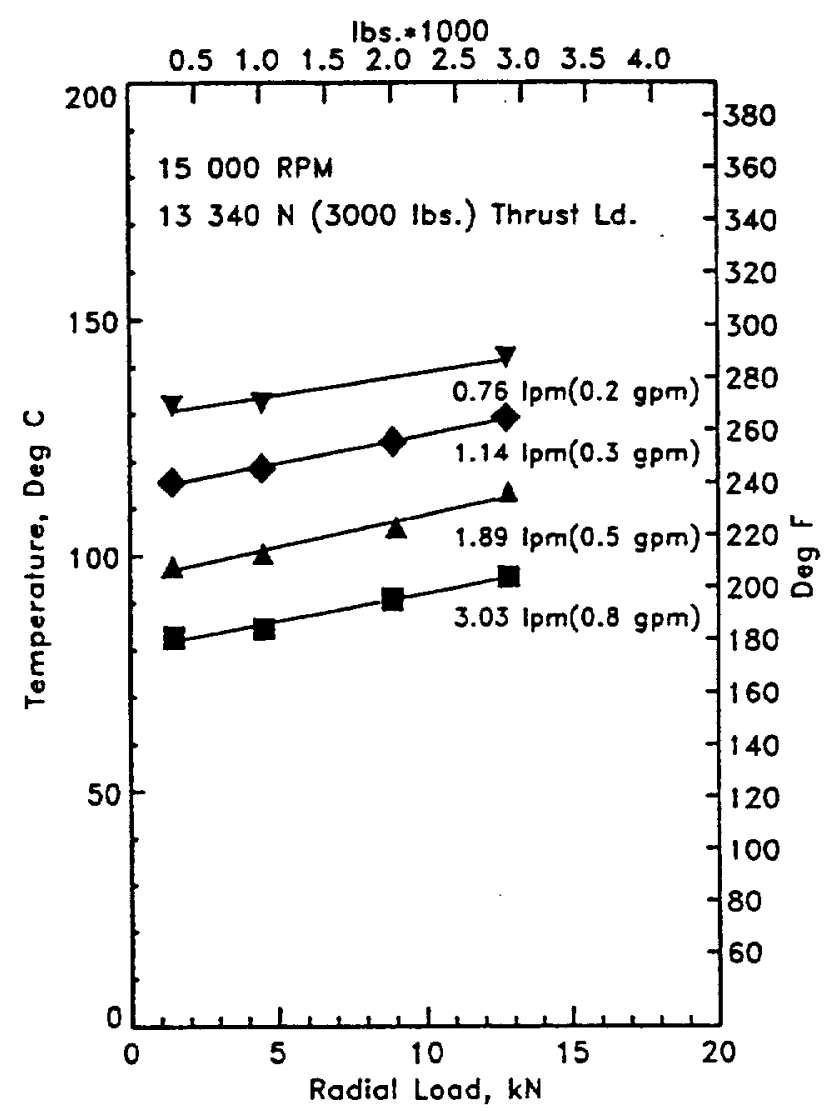

Figure 4. Effect of Radial Load on Outer Ring Temperature for Various RP-1 Flow Rates

versus thrust load, these curves do not give the same temperature when extrapolated to zero radial load. In this instance, the various RP-1 flow rates provide different cooling rates for the bearing at the given speed and thrust load condition and, therefore, different bearing outer ring temperatures.

The change in bearing temperature as a function of shaft speed is shown in Fig. 5 at four different RP-1 flow rates. Note that the bearing temperature is highly dependent upon shaft speed. In fact, doubling the speed from $10000 \mathrm{rpm}$ to 20000 rpm doubles the bearing temperature for each flow rate from 3.03 to $1.14 \mathrm{lpm}$. Moreover, a least-squares curve fit of temperature versus speed for each flow rate yields a second order relationship of the form:

$$
\mathrm{T},{ }^{\circ} \mathrm{C}=\mathrm{S}_{0}+\mathrm{S}_{1} \omega+\mathrm{S}_{2} \omega^{2}
$$

where $\omega$ is shaft speed in rpm and the coefficients, $\mathrm{S}_{0}, \mathrm{~S}_{1}$, and $\mathrm{S}_{2}$ are given in Table VII. 


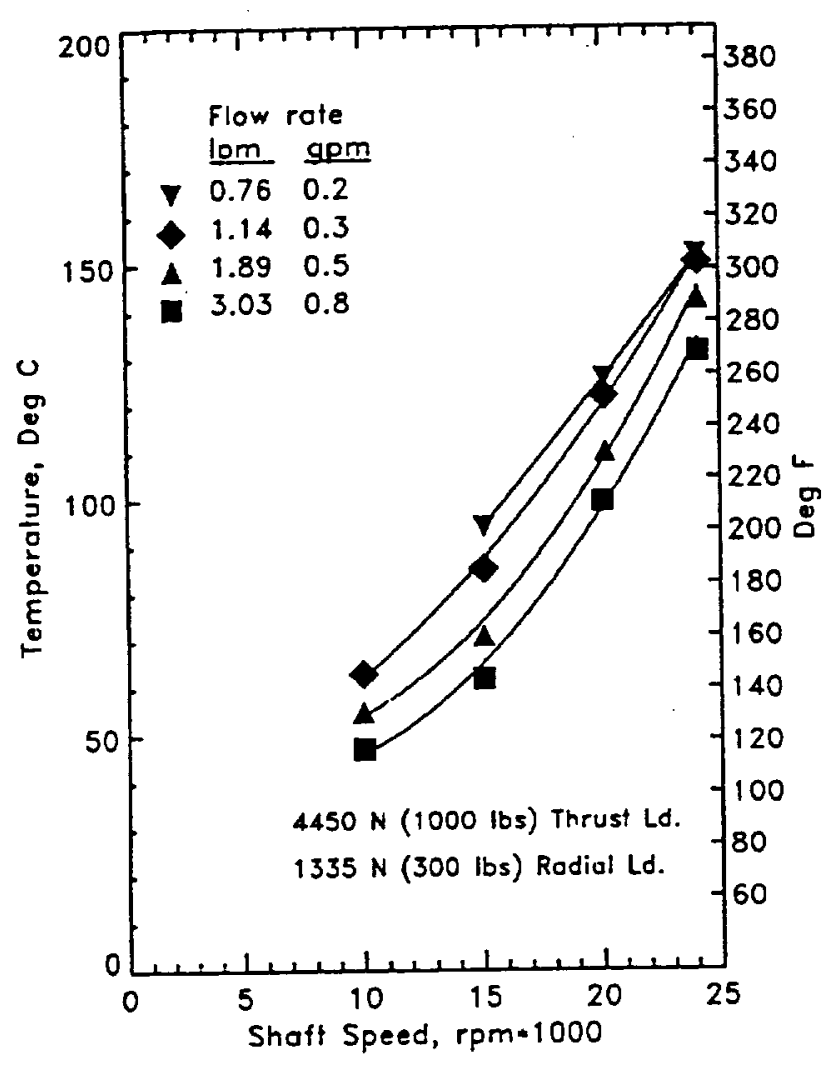

Figure 5. Effect of Speed on Outer Ring Temperature at Various RP-1 Flow Rates

\section{Effect of RP-1 Flow to Test Bearing on Bearing Temperature}

The effect of RP-1 flow to the test bearing on bearing temperature is shown in Fig. 6. At a given shaft speed, reducing RP-1 flow rate increases bearing temperature, although not as dramatically as increasing shaft speed at a given RP-1 flow rate. Here, a least squares curve fit of bearing temperature versus flow rate for each shaft speed yielded a relationship of the form:

$$
\mathrm{T},{ }^{\circ} \mathrm{C}=\dot{\mathrm{V}}_{0}+\dot{\mathrm{V}}_{1} / \dot{\mathrm{V}}
$$

TABLE VII. - TEMP. VS. SPEED COEF.

\begin{tabular}{|c|c|c|c|}
\hline $\begin{array}{l}\text { Flow rate } \\
\text { lpm gpm }\end{array}$ & $\underline{S}_{0}$ & $\underline{S_{1}}$ & $\underline{\mathrm{S}_{2}}$ \\
\hline $\begin{array}{ll}0.76 & 0.20\end{array}$ & 30.0 & 3.30 & 0.073 \\
\hline $1.14 \quad 0.30$ & 31.0 & 1.80 & 0.13 \\
\hline 1.890 .50 & 33.0 & 0.079 & 0.18 \\
\hline $3.03 \quad 0.80$ & 33.0 & -0.85 & 0.21 \\
\hline
\end{tabular}

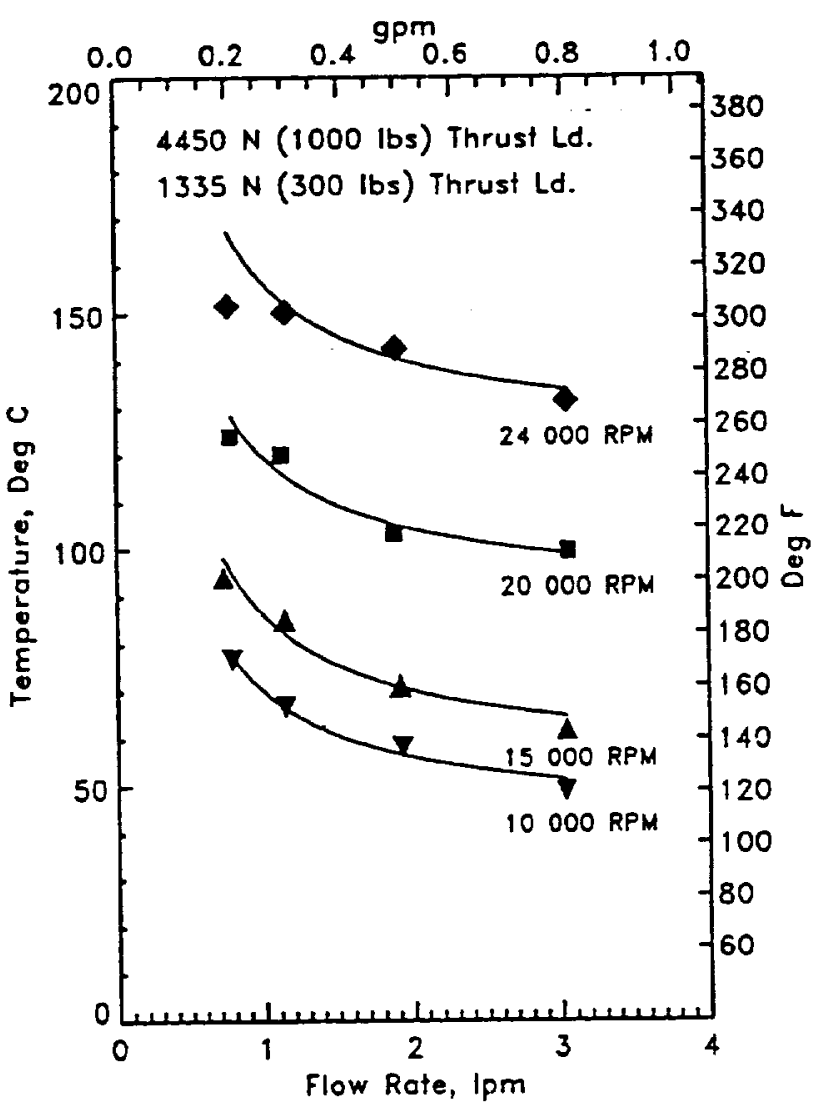

Figure 6. Effect of RP-1 Flow Rate on Outer Ring Temperature at Various Speeds

where $\dot{V}$ is the volumetric flow rate in $1 p m$ and coefficients $\dot{\mathrm{V}}_{0}$ and $\dot{\mathrm{V}}_{1}$ are given in Table VIII.

TABLE VIII. - TEMP. VS. FLOW RATE COEF.

\begin{tabular}{|c|c|c|}
\hline Shaft Speed & $\underline{\dot{\mathrm{v}}_{0}}$ & $\underline{\dot{V}}_{1}$ \\
\hline 10000 & 42.5 & 27.3 \\
\hline 15000 & 54.4 & 31.5 \\
\hline 20000 & 88.9 & 30.6 \\
\hline 24000 & 123. & 33.9 \\
\hline
\end{tabular}

Note that at $24000 \mathrm{rpm}$ and a flow rate of $0.76 \mathrm{lpm}$ $(0.2 \mathrm{gpm})$ the bearing temperature is lower than what is predicted by the characteristic curve drawn through the other three points. Here, the outer surface of the bearing's outer ring is above $150^{\circ} \mathrm{C}$ $(300 \mathrm{~F})$. It was observed that the lubricating and cooling capabilities of the RP-1 begin to change when this part of the bearing reaches $150^{\circ} \mathrm{C}\left(300^{\circ} \mathrm{F}\right)$. This would occur if the contacting surfaces of the balls and rings of the bearing had reached the temperature at which RP-1 begins to boil. Since RP- 
1 is a mixture of different hydrocarbons, it boils over a range of temperatures. The phase change of some of the RP-1 constituents would act as an effective cooling mechanism. However, if too much RP-1 changes phase, the thin lubricating film upon which a rolling element bearing depends is lost. When this occurs, the bearing quickly overheats and failure becomes imminent.

\section{Effect of Speed and Lubricant Flow on Power Loss to the Lubricant}

Shaft power is lost in a ball bearing primarily through frictional heating of the bearing components and through churning ${ }^{10}$ of the lubricant. The increase in lubricant temperature is affected by frictional heating of the bearing components, the churning action, and the dissipation of energy due to viscous forces acting in the lubricant. Therefore, the amount of energy absorbed by the lubricant is an indication of the shaft power lost in a bearing. This quantity can be calculated by the expression:

$$
\mathrm{Q}_{T}=\dot{\mathrm{M}} \mathrm{C}_{P}\left(\mathrm{~T}_{\text {out }}-\mathrm{T}_{\text {in }}\right)
$$

where

$$
\begin{aligned}
& \mathrm{Q}_{T}=\begin{array}{c}
\text { total energy transfer rate } \\
\text { to the lubricant, } \mathrm{kW}(\mathrm{Btu} / \mathrm{s})
\end{array} \\
& \dot{\mathrm{M}}=\text { mass flow rate, } \mathrm{kg} / \mathrm{s}\left(\mathrm{lb}_{\mathrm{m}} / \mathrm{s}\right) \\
& \mathrm{C}_{P}=\text { specific heat, } \mathrm{kJ} / \mathrm{kg}-{ }^{\circ} \mathrm{C}\left(\mathrm{Btu} / \mathrm{lb}_{\mathrm{m}}-\mathrm{F}\right) \\
& \mathrm{T}_{\text {out }}=\mathrm{RP}-1 \text { outlet temperature, }{ }^{\circ} \mathrm{C}\left({ }^{\circ} \mathrm{F}\right) \\
& \mathrm{T}_{\text {in }}=\mathrm{RP}-1 \text { inlet temperature, }{ }^{\circ} \mathrm{C}\left({ }^{\circ} \mathrm{F}\right)
\end{aligned}
$$

The results of the energy transfer calculations for 15000 and $20000 \mathrm{rpm}$ at a $4450 \mathrm{~N}$ $(1000 \mathrm{lb}$.) thrust and $1335 \mathrm{~N}(300 \mathrm{lb}$.) radial load condition are shown in Fig. 7 as a function of RP-1 flow rate to the test bearing. The energy transfer to the lubricant increased with increasing RP-1 flow rate as well as with increasing speed. The sharp increase in heat energy transfer rate with increasing RP-1 flow rate is an indication that this type of bearing should be operated at a low RP-1 flow rate to minimize shaft power loss. However, as previously indicated, the RP-1 flow rate must be high enough to prevent the bearing from reaching the temperature at which RP-1 begins to boil because the probability of losing the RP-1 lubricating film at the contacting surfaces of the bearing becomes too high.

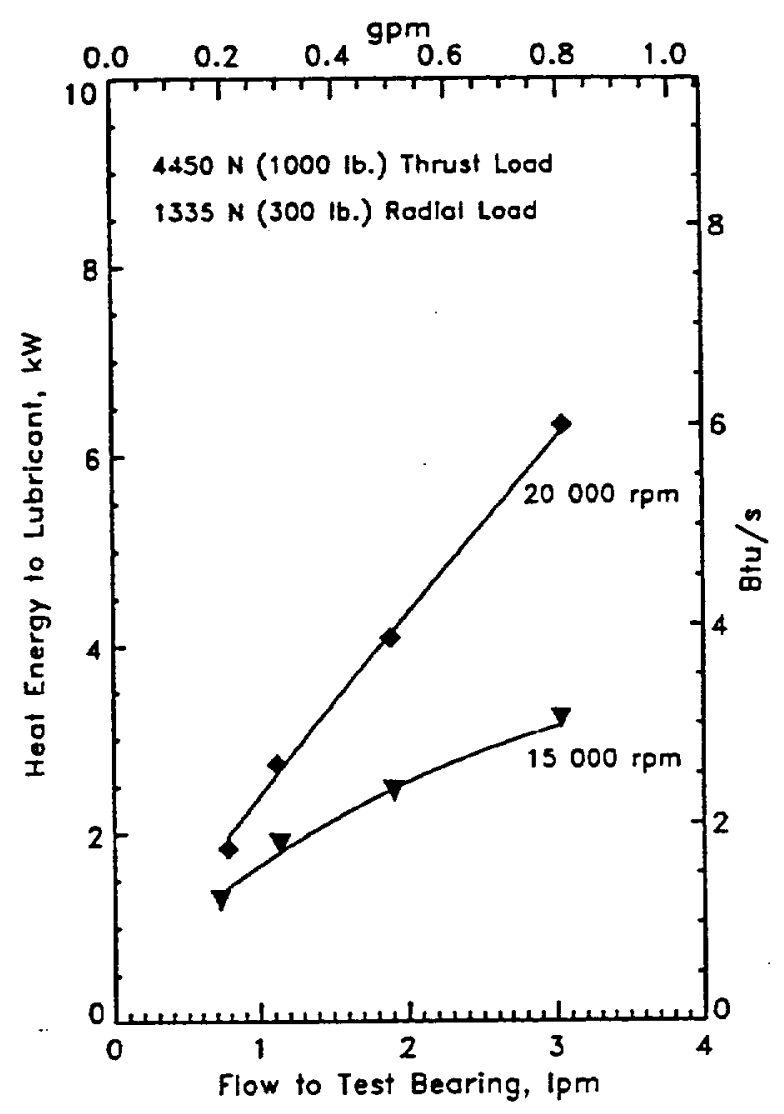

Figure 8. Effect of RP-1 Flow Rate to the Test Bearing on Heat Energy Transfer to the Lubricant for Different Shaft Speeds

\section{CONCLUDING REMARKS}

Parametric tests were conducted in a ball bearing test rig with an 85 millimeter angular contact ball bearing using the hydrocarbon liquid RP-1 fuel as a lubricant. The RP-1 was supplied to the test bearing through an annular jet ring located directly adjacent to the test bearing outer ring. The RP-1 hydrocarbon liquid fuel met the MIL-S-25576C specification. The test bearing was run at a maximum speed of 24000 RPM while being subjected to a thrust load of $4450 \mathrm{~N}$ (1000 lbs.) and a radial load of $1335 \mathrm{~N}$ (300 lbs.). At a speed of 15 $000 \mathrm{RPM}$, the thrust loads were varied from $4450 \mathrm{~N}$ (1000 lbs.) to $17800 \mathrm{~N}$ (4000 lbs.) while holding the radial load at a constant $1335 \mathrm{~N}$ (300 lbs.). Also, at the speed of 15000 RPM, the radial loads were varied from $1335 \mathrm{~N}$ (300 lbs.) to $13350 \mathrm{~N}$ (3000 lbs.) while holding the thrust load constant at 13 $350 \mathrm{~N}$ (3000 lbs.). The test bearing was subjected to 
the maximum Hertzian contact stress level at the 15 000 RPM speed with thrust and radial loads set at $13350 \mathrm{~N}$ (3000 lbs.). The Hertzian contact stress level at these conditions was calculated to be 2802 $\mathrm{N} / \mathrm{mm}^{2}(406,400 \mathrm{psi})$.

The effect of changing RP-1 flow rate to the test bearing on bearing temperature was less dramatic than the effect of changing shaft speed, but more dramatic than changing thrust or radial load, on bearing temperature. This indicates the relative importance of these four parameters on bearing outer ring temperature.

In addition, the safe outer ring temperature limit for a ball bearing operating in RP- 1 is $150^{\circ} \mathrm{C}$ $\left(300^{\circ} \mathrm{F}\right)$ as measured at the outer surface of the outer ring of the bearing. At this condition, the local surface temperature of the balls and contacting ring surfaces are at the point at which the RP-1 begins to boil. Although this can act as an effective cooling mechanism, too much phase change of the RP-1 will result in a loss of the lubricating film and in a rapid bearing overheat. However, increasing the RP-1 flow to the bearing in order to reduce its operating temperature, dramatically increases the shaft power lost to the bearing due to churning of the liquid RP1. Thus, a balance must be struck in a bearing system design between a safe bearing operating temperature and the amount of shaft power lost.

\section{REFERENCES}

1. Butner, M. F. and Rosenberg, J. C., "Lubrication of Bearings with Rocket Propellants", Lubrication Engineering, January, 1962, p. 12-44.

2. "Liquid Rocket Engine Turbopump Bearings", NASA SP-8048, March, 1971, p. 6.

3. Butner, M. F., "Propellant Lubrication Properties Investigation", DTIC Technical Report WADD TR 61-77-PT-1, December, 1961, p. 50-66.

4. Schuller, F. T., "Operating Characteristics of a Three-Piece-Inner-Ring Large Bore Roller Bearing to Speeds of 3 Million DN", NASA TP-2355, August, 1984.

5. CPIA/M Liquid Propellant Manual, Unit 20, RP-1, p. 3.

6. Howell Hydrocarbons, Inc., MSDS Number: H1590, February, 1989, p. 1-2.

7. Dean, L. E. and Shurley, L. A., "Characteristics of RP-1 Rocket Fuel", TCR-70, Library; AeroJetGeneral Corporation, February, 1957, p. 3-4.

8. Hadden, G. B., Kleckner, R. J., Ragen, M. A., and Sheynin, L., "Steady State and Transient Thermal Analysis of a Shaft Bearing System Including Ball, Cylindrical, and Tapered Roller Bearings", NASA CR No. 165365, May, 1981.

9. Addy, Jr., H. E. and Schuller, F. T., "Operating Characteristics of an 85-mm Ball Bearing in RP-1 to 1.7 Million DN", NASA CP-9174, Vol. II, pp.471483, May, 1992.

10. Bisson, Edmond E. and Anderson, William J., “Advanced Bearing Technology”, NASA SP-\$8, pp. 169-172, 1964. 


\section{REPORT DOCUMENTATION PAGE}

Public reporting burden for this collection of information is estimated to average 1 hour per response, including the time for reviewing instructions, searching extsting data sources, gathoring and malntaining the data needed, and completing and reviowing the collection of imformation. Send comments regarding this burden estimate of any other aspect of this Davis Highwray, Sulte 1204, Artington, VA 22202-4302, and to the Otfice of Management and Budget, Papenwork Roduction Projed (0704-0186), Washington, DC 20503.

\begin{tabular}{|l|l|l} 
1. AGENCY USE ONLY (Laave blank) & $\begin{array}{c}\text { 2. REPORT DATE } \\
\text { June } 1993\end{array}$ & $\begin{array}{r}\text { 3. REPOAT TYPE AND DATES COVERED } \\
\text { Technical Memorandum }\end{array}$
\end{tabular}

4. TITLE AND SUBTITLE

5. FUNDING NUMBERS

Lubrication of an 85-mm Ball Bearing with RP-1

6. AUTHOR(S)

WU-584-03-11

Harold E. Addy, Jr. and Frederick T. Schuller

7. PERFORMING ORGANZATION NAME(S) AMD ADDRESS(ES)

National Aeronautics and Space Administration

Lewis Research Center

Cleveland, Ohio 44135-3191

Q. PERForIING ORGANIZATION REPORT NUMBER

E-7978

9. SPONSORINGMONTORING AGENCY NAME(S) AND ADDRESS(ES)

10. SPONSORINGMONTORING

AGENCY REPORT NUUBER

National Aeronautics and Space Administration

Washington, D.C. 20546-0001

NASA TM-106254

AIAA-93-2538

\section{SUPPLEMENTARY NOTES}

Prepared for the 29th AIAA Joint Propulsion Conference and Exhibit sponsored by the AIAA, SAE, ASME, and ASEE, Monterey, California, June 28-30, 1993. Harold E. Addy, Jr., NASA Lewis Research Center, and Frederick T. Schuller, Sverdrup Technology, Inc., Lewis Research Center Group, 2001 Aerospace Parkway, Brook Park, Ohio 44142. Responsible person, Harold E. Addy, Jr., (216) $977-7467$.

\section{DISTRIBUTION/AVALABILTTY STATEMENT}

12b. DISTRIBUTION CODE

Unclassified - Unlimited

Subject Category 15

13. ABSTRACT (Maximum 200 words)

A parametric experimental investigation of an 85 millimeter bore angular contact ball bearing running in RP-1 fuel was performed at speeds of 10000 to 24000 RPM. Thrust loads were varied from 4450 to 17800 Newtons (1000 to $4000 \mathrm{lbs}$.). Radial loads were varied from 1335 to 13350 Newtons ( 300 to $3000 \mathrm{lbs}$.). RP-1 lubrication for the bearing was provided through a stationary jet ring located adjacent to the test bearing outer ring. Increases in both the thrust and radial loads resulted in increased bearing temperature, while increases in shaft speed resulted in much more dramatic increases in bearing temperature. These trends are typical for ball bearings operating under these types of conditions. Results are given for outer ring temperatures of the test bearing at the various test conditions employed. In addition, the heat energy removed from the bearing by the RP-1 was determined by measuring the increase in temperature as the RP-1 passed through the bearing. Results showed that the amount of heat energy removed by the RP-1 increased with both shaft speed and RP-1 flow rate to the bearing.

\begin{tabular}{|c|c|c|c|}
\hline \multicolumn{3}{|c|}{$\begin{array}{l}\text { 14. SUBNECT TERMS } \\
\text { RP-1; Angular contact ball bearing }\end{array}$} & \begin{tabular}{|}
$\begin{array}{l}\text { 15. NUMBER OF PAGES } \\
12\end{array}$ \\
AO3 \\
$\begin{array}{l}\text { 16. PAICE CODE } \\
\text { 20. LMITATION OF ABSTRACT }\end{array}$ \\
\end{tabular} \\
\hline $\begin{array}{l}\text { 17. SECURTY CLASSIFICATION } \\
\text { OF REPORT } \\
\text { Unclassified }\end{array}$ & $\begin{array}{l}\text { 18. SECURITY CLASSIFICATION } \\
\text { OF THIS PAGE } \\
\text { Unclassified }\end{array}$ & $\begin{array}{l}\text { 19. SECURITY CLASSIFICATION } \\
\text { OF ABSTRACT } \\
\text { Unclassified }\end{array}$ & \\
\hline
\end{tabular}

